\title{
Voicing Le Neutre in the invisible choir in Richard Wagner's Parsifal
}

\author{
Anne Sivuoja-Gunaratnam \\ Sibelius Academy, DocMus, \\ Töölönkatu 28, 00260, Helsinki, Finland \\ e-mail: asivuoja@siba.fi
}

\begin{abstract}
Roland Barthes was suspicious about the ability of music and voice to signify, as revealed in many of his writings. However, his somewhat limited views on music and voice need not to restrain from profiting his semiotic theorising and his reasoning, which can be adapted for musical instances in ways not envisaged by Barthes. The Neutral (Le Neutre) is a recurrent topic in Barthes's oeuvre from his first book, Writing Zero Degree (1953) up to his 1978 lecture series on The Neutral in Collège de France (published in 2002). This paper explores how Barthes's Neutral may enhance a special kind of listening. The enigmatic sonorities emitted by the Invisible Choir in Richard Wagner's Parsifal (1882) serve as the foil in this task, more precisely a phrase voiced by female altos and male tenors ("Nehmet hin meinen Leib [...]", Act I). It is not its semantic content mediated by (written) language that is of interest here but how this phrase has been voiced, and furthermore, how Barthes's Neutral may be heard in and beneath it. Several commercially available live recordings made in Bayreuth have offered playground for listening to and for The Neutral. As my analysis shows, the audible Neutral is not a separate entity but works in conjunction with other modes of signification: visual, textual, biographical, spatial.
\end{abstract}

Roland Barthes is an interesting semiotician for a musicologist, because voice and music were his passions, and he wrote about them on several occasions. However, they remained for him much too enigmatic for the needs but also for a competence of a music specialist. In his research, voice and music are in a continuous danger of being swallowed by an all-embracing jouissance, which undoes the culturally determined codes and liberates them from the burden of signification (cf. also Välimäki 2005; Sivuoja-Gunaratnam 2007). In 
this article I want to carry this burden a little further and argue for the possibilities of audible voices to signify, not something in general but something specific: Barthes's Le Neutre (2002; 2005). The enigmatic sonorities emitted by the Invisible Choir in Richard Wagner's Parsifal (1882) serve as the foil in this task. A single phrase is sufficient for the needs of this article. It is not its semantic content mediated by (written) language that is of interest here but how this phrase has been voiced, and furthermore, how The Neutral ${ }^{1}$ may be heard in and beneath it. Several commercially available live recordings made in Bayreuth (listed in the bibliography) have offered playground for listening to and for The Neutral.

\section{Tracing the Barthes's Neutral}

The Neutral has a curious history within Barthes's own oeuvre. It surfaces in his literary production every now and then since his first book, Le degré zéro de l'écriture (1953) where Barthes sets the neutral writing against the petit-bourgeois realistic tradition (Barthes 1984: 5663). Neutral writing does not pretend to express or represent anything. Instead, neutral writing tends to free itself from social and historical contexts. In the chapter Writing and Silence there are manifesto-like formulations that idealize the neutral as a literary practice:

This transparent form of speech, initiated by Camus's Outsider, achieves a style of absence which is almost an ideal absence of style; writing is then reduced to a sort of negative mood in which the social or mythical characters of a language are abolished in favour of neutral and inert state of form; thus thought remains wholly responsible, without being overlaid by a secondary commitment of form to a History not its own. (Barthes 1984: 64)

The Neutral has an entry in Barthes's autobiography (Barthes 1994: 132-133; 1995: 119). In its first sentence Barthes states that the Neutral is "[...] a back-and-forth, an amoral oscillation [...]." He also gives a short list for the Figures of the Neutral, which includes white writing, exempt from any literary theatre, the principle of delicacy, the empty, the vacancy of the 'person' and jouissance. In the end of this

\footnotetext{
1 Le Neutre has been translated as The Neutral (cf. Krauss, Hollier 2005: xiv$\mathrm{xv})$.
} 
entry Barthes asserts that the Neutral is not the third term - zero degree - but the second term in a new paradigm where the primary term is violence (for instance combat, victory, arrogance). Many of these figures and designations formulated by Barthes in the mid-1970s are later (Barthes 2005) elaborated at length. In fact, Barthes (2005: 174) mentions that his course on The Neutral is a remake of his Writing Zero Degree.

Beside these two examples mentioned above, The Neutral shows itself in many other instances in the Barthes's ouvre (for instance in 1977 and 1990). But the parading of The Neutral takes place only late in Barthes's literary career, in his lecture series on The Neutral, held in Collège de France during the spring term of $1978 .^{2}$ In his first lecture Barthes allowed himself almost to define what his Neutral might be.

I define the Neutral as that which outplays \{déjoue the paradigm, or rather I call Neutral everything that baffles [déjoue] the paradigm. For I am not trying to define a word; I am trying to name a thing: I gather under a name, which here is the Neutral. The paradigm, what is that? It's the opposition of two virtual terms from which, in speaking, I actualize one to produce meaning. [...] My definition of the Neutral remains structural. By which I mean that, for me, the Neutral doesn't refer to 'impressions' of the grayness, of 'neutrality,' of indifference. The Neutral - my Neutral - can refer to intense, strong, unprecedented states. "To outplay the paradigm", is an ardent, burning activity. (Barthes 2005: 6-7)

This quasi-definition echoes to a great extent what Barthes wrote some 25 years before in his Writing Zero Degree (Barthes 1984: 64): "[...] we know that some linguistics establish between the two terms of a polar opposition (such as singular-plural, preterite-present) the existence of a third term, called a neutral term or zero element [...]". Curiously these two (1984 and 2005) descriptions of the Neutral do not quite seem to match with the one given in his autobiography, where Barthes (1994: 33) does not equate the Neutral with the third term or degree zero. This "not quite matching" discloses Barthes's Neutral at work; it pivots and oscillates about in such a way that hygienic classifications to neat paradigms are outplayed. These kinds of definitional discrepancies are not that uncommon in Barthes's ouvre, for instance there is an ardent oscillation going on around

2 The manuscript for the lectures was posthumously published in 2002, and translated into English in 2005. 
pleasure and bliss (jouissance) in his The Pleasure of the Text (s.v. Dire and Droit; Barthes 1990: 19-20, 22). ${ }^{3}$

Barthes was not willing to give up his binarism even regarding The Neutral. So there is an anti-Neutral, which is not a Figure of its own right but unavoidably attached to the Figures of the Neutral. Under the Figure of Wou-Wei he describes the anti-Neutral as follows: "Pure expression of the anti-Neutral: obligation to choose, no matter what side: the Neutral is more enemy than the enemy: it's the beast to kill, to exclude: tyranny of the paradigm in all its purity" (Barthes 2005: 183).

The Adjective is for Barthes "[...] the anti-Neutral par excellence, as though there were a constitutional antipathy between the Neutral and the adjective" (Barthes 2005: 52). It is an aggressive tool for predication, setting up paradigms, and keeping them straight. Barthes's dislike for the adjective is evident elsewhere, too (e.g. Barthes 1987: 29-36; see particularly footnote $12^{4}$ ). His The Grain of the Voice (originally from 1972) begins with pouring out his mistrust with the predicative supremacy of adjectives in describing music and Barthes (1997a: 268) asks: "Are we doomed to the adjective?" Barthes's aversion towards adjectives is certainly methodological but perhaps also quite personal. In his lecture series Barthes (2005: 56) admits that "[...] I always receive the adjective badly, as an aggression, and I do so in all cases, no matter which value is attributed to it by the figure under which it is addressed to me".

The relationship of the adjectives and voice is particular for Barthes. The concept 'Grain of the Voice' was designated for addressing music, particularly voice, in a way that would avoid the adjectives and their predicative power (Barthes 1997a: 268-269). Also later Barthes regarded voice as an instrument that frustrates adjectives: "voice $=$ 'object' that resists: sparks off adjectives (soft, startling, white, neutral, etc., voice), but nothing more" (Barthes 2005: 78).

\footnotetext{
3 The oscillation between plaisir and jouissance is further (and unintentionally) reinforced by translations, where their difference is not recognized. Also, signification (signification) and signifying (signifiance) are in the risk of being confused in translations. See also footnote 22 !

4 I thank Maria O'Sullivan for bringing this last mentioned adjective-list to my knowledge.
} 


\section{Androgyne as a Figure of the Neutral}

The Androgyne is the last Figure of the Neutral delivered by Barthes in his course. He had prepared three more Figures - Intensities, To Give Leave and Fright - which he did not have time to speak but they nonetheless have been published in the book. Barthes says that he could have begun with The Androgyne, had his aleatoric system of arranging the order not thrown it the last (dernière), but not final (ultime) (Barthes 2005: 186).

Barthes (2005: 191-192) strongly distinguishes hermaphrodite from the androgyne. For him hermaphrodite is a kind of farce mode of androgyne, because it stays at the level of genitality. Androgyne proper is a metaphor, not a medical case, and in this metaphor genitality has been dispersed to secondary attributes, from femaleness and maleness to femininity and masculinity:

The androgyne thus is the Neuter, but a Neuter conceived as the complex degree: a mixture, a dose, a dialectic, not of man and woman (genitality) but of masculine and feminine. Or better yet: the man in whom there is feminine, the woman in whom there is masculine. (Barthes 2005: 193.)

Those Barthes connaisseurs familiar with his $S / Z$ and particularly his essay Masculin, féminin, néutre $(1970)^{5}$ — both of them addressing the castrato La Zambinella, a fictive character in Honoré Balzac's short story Sarrasine - would probably have expected Barthes to discuss castrati as a typical case of The Androgyne and of The Neutral. However, he does not do that. In the beginning of the lecture on The Androgyne, he briefly mentions a radio program where countertenors had been heard (Barthes 2005: 186), but there is no further elaboration of their possible interconnection. Here or elsewhere Barthes never really acknowledges the castrato's voice, their raison d'être. Instead of accepting castrati's vocal (and aural) dimension, Barthes approaches them as visual phenomena, considering their costumes (distribution

\footnotetext{
5 Barthes (1970: 899) erroneously claims that the two last castrati had died in 1846 and 1861. Obviously he was not aware of Alessandro Moreschi (1858-1922) whose recordings from 1902-1904 have survived (see, e. g., Clapton 2004). Hear also Alessandro Moreschi: The Last Castrato. Complete Vatican Recordings. Opal CD 9823 (1984, 1987). The glorious vocal virtuosity of the castrati should not be deemed on the basis of this recording.
} 
vestimentaire) and how to show their gender in a text (Barthes 1970: 900, 905-907). Barthes emphasizes seeing when in the Balzac's Sarrasine the sculptor Sarrasine witnesses an opera performance starred by La Zambinella. Yet in Balzac's short story the musico's voice is described at length (see below). Furthermore, Barthes doesn't even mention the voice when he lists proofs for why Sarrasine deduces that (La) Zambinella must be a woman (Barthes 1970: 902, 904-905). (La) Zambinella's three decisive feminine predicates ${ }^{6}$ for Sarrasine according to Barthes — are: (1) La Zambinella's beauty; (2) her fragility and weakness; and (3) Sarrasine's own passion which he can only imagine to be roused by a women. ${ }^{7}$

In $S / Z$, Barthes's more extensive study on Balzac's short story, he devotes some passages not actually for La Zambinella's voice but for the effects it rouses. This is not quite in line with Balzac's text where the singer's voice is the most ravishing channel to Sarrasine: "When La Zambinella sang, the effect was delirium" (Balzac quoted in Barthes 1992: 238; fragments 230-231). In his interpretation Barthes (1992: 115) symptomatically again ignores the castrato's voice. The voice and the act of singing only refer to 'Theater' and to 'Aria.' Barthes's reluctance or rather, refusal to address voice is even more salient in his comment on the following fragment (Nr. 243) in Balzac's short story, which describes La Zambinella's voice:

Last, this agile voice, fresh and silvery in timbre, supple as a thread shaped by the slightest breath of air, rolling and unrolling, cascading and scattering, this voice attacked his soul so vividly [...]. (Balzac quoted in Barthes 1992: 239; fragment 243.)

In his interpretation Barthes (1992: 118) completely bypasses the first part of the fragment that concerns voice and concentrates on being penetrated by the voice. This is, besides being unfair to Balzac's excellent sentence, yet another instance when voice alone, without tied

6 Unlike Barthes, Sarrasine was not suspicious about adjectives and predications and had to pay highly for his error.

7 This assertion is questioned by Dame (1994: 146-147) who claims that Sarrasine feels repulsion for every woman. I do not share her interpretation at this point: Sarrasine did have a sexual relationship for instance with Clothilde before his journey to Rome and his baffling encounter with La Zambinella in Teatro Argento. 
to a natural language, means practically nothing for Barthes. ${ }^{8}$ The castrato's voice is a double nothing, because besides voice also castrato stands for a void or absence in signification (Barthes 1970: 900-901).

In order to make any progress, I had to drop the Barthesian lead on castrati, as it turned out to be a blind alley regarding voice and signification. But I did not drop Barthes. Instead, I read his chapter on The Androgyne further down and found his remarks on Leonardo da Vinci based on Freud's famous study about Leonardo's childhood memory (Freud 1984). Although they seemingly had nothing to do with voice, they nevertheless guided my aural perception of the Neutral in the voices. And furthermore, Leonardo da Vinci's art forms a surprising bridge between Barthes (after Freud) and Wagner, which rests on the neutrum/Le Neutre.

\section{Bridging Leonardo da Vinci, Wagner, Freud, and Barthes through neutrum}

Siegmund Freud's famous study on Leonardo da Vinci's childhood memory is a screen through which Barthes looks at Leonardo's paintings and reads about his life. In The Neutral there is no reference to Leonardo without Freud (Barthes 2005: 168, 177, 194-195, and 207-208). Both Freud and Barthes share an interest in Leonardo's childhood memory: a vulture (or more correctly: a kite) had landed down to Leonardo's cradle and stuck the infant several times with its tail (Freud 1984: 29, 33). For Barthes (after Freud) this scene depicts a fantasma of a maternal vulture deity, combining both masculine and feminine features, the phallus (tail) and the breast. Referring to Freud Barthes emphasizes the androgynous (and not hermaphrodite) nature of this kind of mother. Like Freud, also Barthes brings in homosexuality embedded in this scene, but Freud takes a longer detour than

8 Barthes's indifference to voice as a significatory practice often remains unnoticed. For instance, Mary Ann Smart sums up $S / Z$ 's meaning for opera studies as following: "Although Roland Barthes's S/Z predates musicological interest in gender issues by nearly two decades and has only episodically had any influence on writing about opera, Barthes's multifaceted reading of Balzac's story 'Sarrasine' marks out an attractive theoretical ground by showing how exploding the fundamental opposition male/female can lead to the collapse of other epistemological categories, including that between systematic analysis and operatic jouissance" (Smart 2000: 8). 
Barthes into the Leonardo's alleged sexual history, whereas Barthes keeps away from Leonardo the person and confines himself to this (textualized) scene only. (Barthes 2005: 194; cf. Freud 1984: 29-50.)

Barthes obviously chooses only few issues from Freud's abundant essay. Unlike Freud (1984: 20-29) Barthes doesn't address Leonardo's dual nature as an artist and researcher, which is a topic not far removed from Barthes's own approach (cf. Barthes 2005: 64). This pivoting between art and research is for Freud yet another feature signalling Leonardo's unstable (sexual) identity. Freud even mentions that homosexual men willingly would refer to themselves as a "third sex", an interpretation not accepted by Freud himself (1984: 47); and again there is no reference to this in Barthes.

For me, the apical issue in Leonardo's childhood memory is the mouth, as it is the locus of voice and language. In many of Leonardo's paintings the mouth becomes a particularly active site when both feminine and masculine traits are androgynously intertwined in the oral zones: see for instance Mona Lisa, Leda (in Leda and the Swan), St. John the Baptist or Bacchus (Barthes 2005: 195; cf. also Freud 1984: 57-68; Fig. 1). When I look at these paintings, I also recognize the pivoting of femininity and masculinity. But even more titillating is to imagine what kind of voices these figures would have had and how would they have spoken.

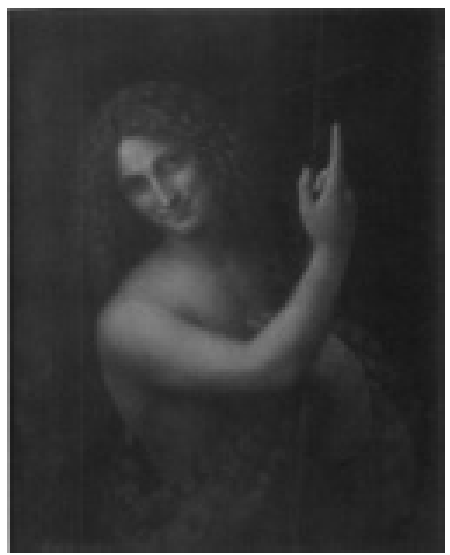

Figure 1. Leonardo da Vinci, St. John the Baptist (1513-1516, oil on walnut wood, displayed at Louvre) (from Mannering 1987: 70). 


$$
* * *
$$

Curiously, some thirty years before Freud, another German genius had discussed Leonardo's certain painting as a case of a neutrum, namely Richard Wagner (1813-1882). ${ }^{9}$ In March 1859, Wagner had visited Milan and the nearby Santa Maria delle Grazie which houses Leonardo's famous Last Supper (1495-1498; Fig. 2). In his autobiography Wagner describes the event as follows:

Yet I gained a deeper insight into the effect produced by the purely artistic significance of a painting when I stood before Da Vinci's Last Supper and had the same experience as everyone else. The original work has deteriorated so badly that the paint is almost entirely ruined, yet after one has examined more closely the copies reconstructing the original, which are placed permanently alongside it, and then turns again from the copies to the ruin of the original, everyone experiences, as I did, that one's eye has become visionary, and one suddenly perceives with the greatest clarity what it is that cannot be copied. (Wagner 1992: 584-585; cf. also Glasenapp 1905a: 308)

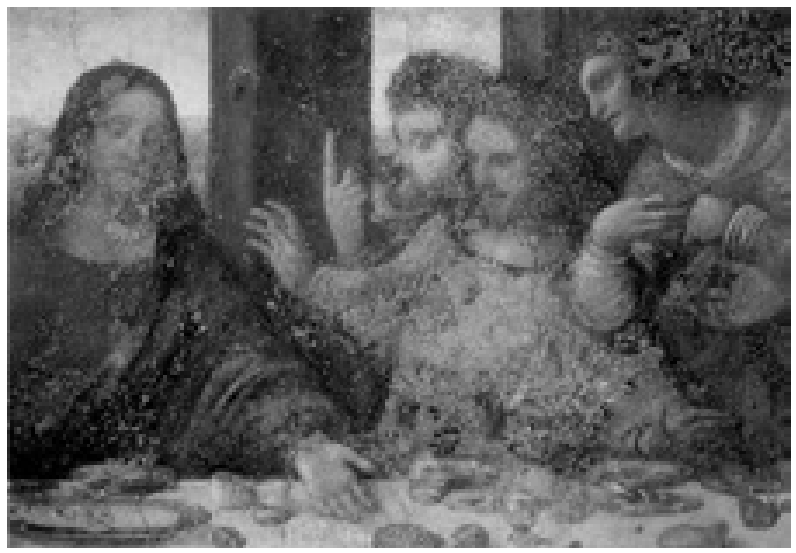

Figure 2. Leonardo da Vinci, Last Supper (1495-1498), a detail (from Mannering 1987: 43).

9 Here Freud makes no reference to Richard Wagner. His name surfaces in Freud's writings very seldom, mainly through the accounts of his patients. Freud's silence of Wagner's output has raised justified questions among scholars (see Díaz de Chumaceiro 1993). It is undeniable that in his operas and writings Wagner processed issues that were to become topical in Freud's research: father-son relationship, castration, love, dreams and fantasies. 
The subject matter of the Leonardo's painting, the Holy Communion, became topical to Wagner when he was composing both the text and the music for his last opera, Parsifal ${ }^{10}$. During the composition process Wagner needed to settle how to build up as music the Holy Communion, and particularly the Institution of the Lord's Supper, which according to Christian scriptures quotes Christ's words. In Wagner's imagination Christ's voice had to be something extraordinary, as he had expressed to his wife Cosima:

But in order to impart the spiritual quality of Christ's words, their detachment from all material things, he intends to use a mixture of voices: 'A baritone voice, for example, would make it all sound material; it must be neither man nor woman, but neuter ${ }^{11}$ in the highest sense of the word'. (Cosima Wagner's diary entry 26 Sept 1877; Wagner 1994: 289)

A couple of years later Wagner made a direct reference to Leonardo's Last Supper in which he had been inspired by the almost womanly Christ with a beard. But, as he had mentioned to his wife, Christ's head in Leonardo's sketches for the Cena was too feeble (weichlich). Curiously, Nattiez underestimates the Leonardo connection:

The allusion to Leonardo da Vinci might suggest that we were in the presence of that ambiguous androgyny typical of the end or the nineteenth century and much prized by the pre-Raphaelites. But there is almost certainly no truth in this interpretation. Ambiguity is not sexual neutrality. (Nattiez 1993: 172)

Wagner's own words penned down by his wife Cosima Wagner testify the contrary of what Nattiez claims:

10 Jean-Jacques Nattiez's Wagner Androgyne (1993) is not discussed here at length because it does not deal with voice but mainly Wagner's artistic person. Nattiez considers Richard Wagner to have two sides intertwined, the male (librettist) and the female (composer of music). According to Nattiez, their emphases have varied during Wagner's long career in his person, his writings and operas. Nattiez considers Parsifal to represent "asexual androgyny that transcends all racial differences" (1993: 171; emphasis in the original). See, however, for instance, Stein (1950), Gutman (1968) and Weiner (1997) who convincingly argue for strong racist (particularly Anti-Semitic) currents in Wagner's writings and music dramas, including Parsifal. Elsewhere I have discussed Parsifal as a case for abjection (Sivuoja-Gunaratnam, forthcoming).

11 In the original, Wagner uses the word neutrum (Wagner 1982a: 1073). 
Thereafter he [Ricahrd Wagner] plays the first theme from Parsifal and comes to me explaining how he has the choir to enunciate the words, so that he [Christ] does not appear either as feminine or masculine; the Christ must be quite extraordinary, not woman or man. This has been also what Leonardo has tried to achieve in his Cena with almost a womanly [weiblich] head with the beard. He should not appear either old or young; the God in human. (Cosima Wagner's diary entry on 27 June 1880; Wagner 1982b: 556; translation and emphasis mine - A. S.-G.; cf. also Glasenapp 1905b: 363)

The words in question are as follows: "Nehmet hin meinen Leib, nehmet hin mein Blut um uns'rer Liebe Willen". This is not a verbatim quote from any of the Gospels although it emulates closely the Institution of the Lord's Supper. ${ }^{12}$ A speciality of the moment is further enhanced by having the Grail Cup radiate at the moment these sacred words are pronounced, as instructed in the score. ${ }^{13}$

Nattiez (1993: 171) erroneously connects Cosima Wagner's diary note (27 June 1880; see above) to the final chorus, which he claims to be the only mixed chorus in the work. First of all, to be precise, there is not a single mixed chorus in Parsifal, because in the four-part choral writing the highest voices are occupied by boy sopranos (not female sopranos), which considerably bends the timbre. Therefore the mixed chorus is not a correct designation. Secondly, as the beginning of the diary entry clearly shows, the words to be voiced are connected to the first theme of the Parsifal, which obviously is not located in the end. The final chorus is only partly associable to the first theme ${ }^{14}$ whereas the theme in "Nehmet hin [...]" is exactly the same as Parsifal's first theme, so called Liebesmahl-Spruch (see, for example

12 "Take my body, take my blood, in token of our love!" (cf. Luke 22: 17-19; Mark 14: 22-24; Matthew 26: 26-28). The order was reversed in the sketches; first was blood and thereafter came the bread (Minor 2005: 5, fn 9; Kinderman 1995: 90). In the Gospels (except for Luke) and in St. Paul's account (1 Corinthians 11: 23-26) the bread is always the first, as it was to be also in Parsifal.

13 Heinrich Porges's (2002: 37) observations confirm that this was actually executed in the first performance, 26 July 1882. The moment of Grail's radiation was indicated already in first and the second versions of the Parsifal libretto in 1865 and 1877 respectively (Geck, Voss 1970: 72, 81).

14 For instance, the final chorus lacks the distinctive Schmerzenfigur motive embedded in the Liebesmahl-Spruch. Furthermore, the final chorus begins with a Thoren-Motive, not to be found in the Liebesmahl-Spruch. (Wolzogen [s.a.]: 17, $63,81$. 
Wolzogen [s.a.]: 17-18, 38-39, 80-81, and Fig. 4). Furthermore, it is false to equate the Invisible Choir with Christ (Sivuoja-Gunaratnam 1993: 347) and consider all its utterances as originating from Him. The words in the final chorus are not to be attributed to Christ but to a less specific divine agent. As the author of the Parsifal libretto, Wagner used quotation marks when an utterance should be considered as a quote. There are no quotation marks in the final chorus; but there are ones around "Nehmet hin [...] Liebe Willen".

Wagner's solution for achieving the neutrum for this particular phrase was quite extraordinary: mixture of female altos and male tenors, which are close to each other in their timbre and vocal range. Their combination produces a strong chest resonance, because the tessitura of the vocal line lies quite low (see Fig. 4). They sing in unison, which further enhances the intelligibility of the text lines: the comprehensibility of the divine words is not risked. Also, the unison unites many voices as a one voice.

In his St. Matthew's Passion J. S. Bach has a bass singer (Jesus) sing the Institution of the Holy Communion. Bach's Jesus (not Christ!) is also visible, flesh and blood, and clearly a male, a human. ${ }^{15}$ In Parsifal, He belongs to the divine order, surpassing human and therefore Wagner was struggling a special way to voice Him. Fourpart choral texture, suggested by Nattiez (1993: 171) would be quite a standard choral writing whereas having altos and tenors in unison is not.

Had he wanted, Wagner could have assigned the alto part to boyaltists, as the tessitura and vocal range of the alto part would have been easily within their reach. This pondering is relevant because the Invisible Choir also include boy sopranos (Knaben). ${ }^{16}$ Why not boy altos, too? This would have led to a different timbre, as the boy altos would have less loud voice and much less chest resonance than female altos. Also it would have been a totally female-free choir, and as a result, the desired androgynous blending of male and female voices, the neutrum Wagner desired, would have been lost. ${ }^{17}$ But although

15 It is well known that Wagner knew St. Matthew's Passion as well as other Bach's pieces (Gregor-Dellin 1980: 785).

16 N.B. The boy sopranos do not sing in this particular phrase. The next sung phrase in Parsifal with boy sopranos and female altos calls for another article.

17 Similarly, omitting all the tenors would destroy the chance for the vocal Neutrum, a point missed by Minor (2005: $4 \mathrm{fn} \mathrm{8)}$ as he states that the "inclusion of 
Wagner employed the voices of female altos, he made a linguistic travesty by casting the women altos as males: they appear as Youths (Jünglinge) along with the tenors in the list of dramatis personae.

The Invisible choir is traditionally placed in the cupola of the Bayreuth opera shrine, high above the stage, on two layers. In the first performance the boy sopranos and four altos were on the highest level in the cupola and the rest, tenors and altos on the middle high level (Geck; Voss 1970: 136). The layered choir remains invisible to the audience (see Fig. 3). The absence of visual clues gives no support to the audience's attempts to sex the voice(s), automatically ignited when one hears a human voice. When the gap between visible (absent) and audible (present) cannot be overcome, the distance of the vocal source cannot be accurately defined (Dolar 2006: 67). ${ }^{18}$ Mladen Dolar points out that these kinds of acousmatic voices are typical representations of deities in various religious rituals. He even proposes that there is

[...] a direct hidden link between the acousmatic voice and divinization. The voice whose source cannot be seen, because it cannot be located, seems to emanate from anywhere, everywhere; it gains omnipotence. Could we go so far as to say that the hidden voice structurally produces 'divine effects'? (Dolar 2006: 62)

In this case the answer is yes. But the invisibility of the choir is only one attribute of the divine. In addition, the quasi-Biblical text, androgynous voices and the acting out of the Holy Communion contribute to the divine effects as well as the temple-like architecture of the setting modelled after the Siena Cathedral (Skelton 1965: 56). ${ }^{19}$ The dimensions of the sets are huge, which effect also how the voices sound. The vertical distance from the stage and reverberation caused by the cupola walls contribute to the ethereality and immateriality of the voices (cf. also Minor 2005: 6-7 who focuses on the unique space created by the voices.) According to Porges (2002: 37), Wagner had described the desired timbre as a cloud traversing the sky.

tenor voices in some of the treble chorus's music (at the same pitch level) is similarly unintelligible".

18 This applies also to the layering, which cannot be deciphered either visually or audibly (Minor 2005: 4 fn 8).

19 Gutman (1968: 403-404) points out that also Dresden's Frauenkirche may have served as a possible model for the Grail temple. 


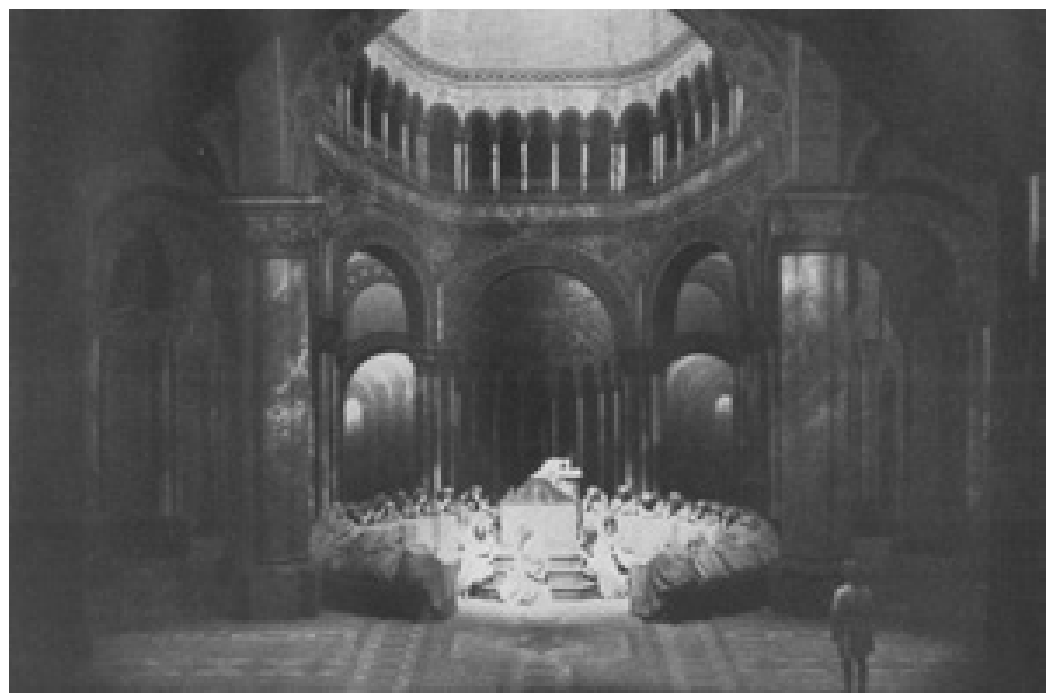

Figure 3. The Hall in the Castle of the Grail (Acts I and III). (Bie 1931, Nr. 74.) This setting was designed by the Russian painter Paul Joukowsky in a strict collaboration with R. Wagner. It remained unaltered up to 1933. As can be seen, the choir in the cupola remains invisible, whereas the Knights of the Grail are seated around the table, Parsifal standing aside. The Vessel of the Grail is in the middle.

\section{Listening for the Neutral}

In the previous chapters the Neutral was discussed in the contexts of Barthes's semiotic theory and Wagner's Parsifal score, his autobiography and Cosima Wagner's diary. The analysis would remain deaf and incomplete without addressing the Neutral in its audible dimension. Therefore I have listened closely to several Parsifal recordings in order to trace the sonorous Neutral. The recordings are with one exception live recordings from the Bayreuth Festspielhaus performances. The only studio recording in my list is the oldest one, from 1927 by Karl Muck (1859-1940). It is most probably based on the Parsifal production given that summer in Bayreuth. It is also the first comprehensive Parsifal recording released commercially. In his times Muck was a considerable Parsifal authority as he conducted the 
work in Bayreuth from 1901 to 1930. All the Parsifal performances up to 1933 followed Richard Wagner's original plan from 1882, which was modernised under the Nazi-regime by Hans Tietjen and Alfred Roller for the 1934 performance.

The Parsifal recording tradition cannot be discussed without the legendary Hans Knappertsbusch (1888-1965) who conducted the infamous 1951 performance of Parsifal which exemplified Wieland Wagner's new austere style of staging, so called Neu-Bayreuth. This Parsifal remained in the Bayreuth programme from 1951 till 1973. Knappertsbusch conducted Parsifal every summer from 1951 till 1964 (with one exception: 1953). He also made several Parsifal recordings from the live performances in 1951, 1952, 1954, 1956, and 19581964. The recordings listened to for this article are from the 1951, 1962 and 1964 performances. After Knappertsbusch, Pierre Boulez, Eugen Jochum, and James Levine have both conducted and recorded Parsifal in Bayreuth. Closest to Knappertsbusch's score comes James Levine (1943-) who has conducted Parsifal in 1982-1985 and 19881993; the 1982 marking the centenary of Parsifal's first performance with the new staging by Götz Friedrich. But he has made only one live recording of Parsifal, in 1985. Pierre Boulez's (1925-) Parsifal account contains the performances in 1966-1968, 1970 as well as 20042005, the last ones for the revolutionary staging by Christoph Schlingenschief. The two recordings, both considered here, are from 1966 and 1970.

I have chosen to limit myself to the live recordings from Bayreuth - the only exception being Karl Muck — because the room acoustic as well as dimensions of the stage, orchestra pit and cupola would remain the same. Also, the relatively slow pace of new stagings gives some stability to the performances. What obviously has changed is the recording technique (e.g. a passage from mono to stereophony and to multi-channel digital technique), including microphones and their placement, editing and post-production. As the listening mode is not here $h i-f i$, this will not be addressed in detail. In order to help the close listening I extracted the short music examples from the original CDs, placed them on a sample CD and listened to the samples several times individually and in succession. ${ }^{20}$ Although I refer to recordings,

20 I have listened some of the excerpts with Hannu Norjanen, the Finnish conductor, and my American colleague José A. Bowen and want to thank them for sharing their expert opinion with me. 
I want to stress that I have close-listened for this analysis only the phrase presented in Fig. 4. What I wanted to find out is whether the Neutral would in fact be audible and if yes, how.
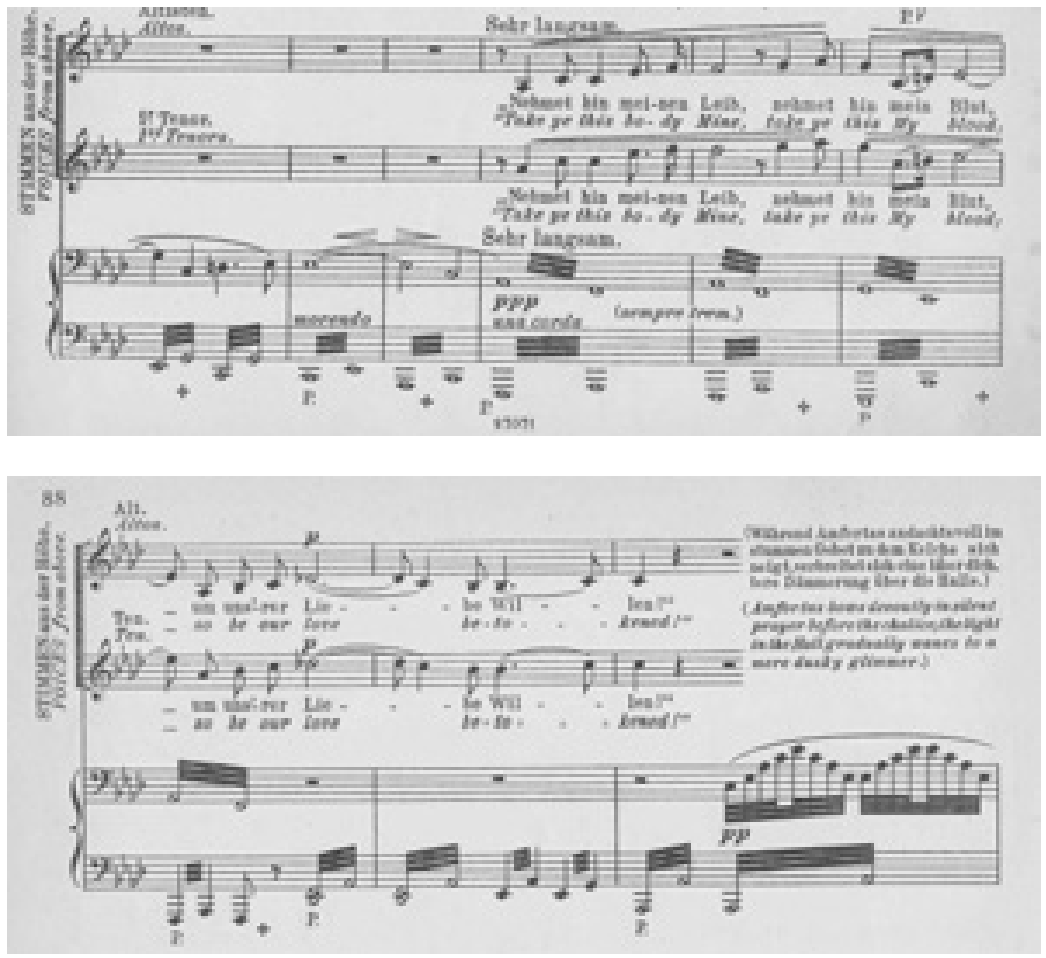

Figure 4. Music example: Richard Wagner, Parsifal, Act I (Piano score, p. 8788). This Grail Motive also inaugurates the opera, but here it appears for the first time with the text. Wagner conceived it as the kernel of everything in Parsifal (Kinderman 1995: 88-91). 
In Muck's recording the tenors overpower to the extent that the maleness of the sonority is firmly established and the female altos are not audible at all. Therefore there is no audible Neutral present. Although this might be an effect of the recording conditions; equipment, placing of the microphone etc., the audible image is what remains and it does not even suggest the presence of altos. Muck's whole recording, including this excerpt, gives a curious testimony of unevenness in articulation and intonation as well as rhythmic inexactness. In this excerpt the choir is hardly in unison, although it should be, and the rhythmic and timbral deviations are more than obvious. The singing body is so uneven that occasionally individual singers can be distinguished. In Muck's version, Christ appears very male and very divided.

The Knappertsbusch 1951 recording sounds as if the tenors did not sing at all. Besides the female altos what can be heard is the distance: the voices come from afar; they are not close by as are for instance the Grail Knights. Particularly the first word 'Nehmet' emerges as if from nowhere, barely distinguishable as a voiced sound invested with language. Unlike in Muck, here the articulation is exact producing a homogenous singing body, but devoid of male timbre.

Also in Knappertsbusch's legendary 1962 recording the female voices dominate but the distinct tenor timbre comes forward particularly in long held tones or where the tenors' vocal line touches the high (= difficult) tones, for instance in the 'Leib, nehmet hin' or particularly in the last syllbale of 'Liebe Willen'. This occasional oscillation of the female and male brushes the Neutral, without however allowing it to be fully present.

In Knappertsbusch's last recording (1964) the tenors are overshadowed by female voices, but as a difference to the previous two versions considered, they are nevertheless audible. The darker timbre of the tenors is faintly present for instance in 'um uns'rer Liebe Willen'. This is not obvious though, and in order to capture this fleeting tenor timbre a version with even more pronounced female vocal presence needs to be called for comparison. Such a recording is Boulez's first Parsifal (1966). Here the alto timbre is much brighter than in any of the previous recordings, and the tenors are not audible at all except for a vanishing moment in 'Liebe Willen'. Boulez was notorious for his fast tempi on Parsifal, and this applies also for this as 
well as the next excerpt, which are much faster than for instance the three Knappertsbusch versions considered previously.

In Boulez's 1970 recording the female and male voices are melted into a curiously homogenous voice, as if there were only one voice singing, a voice that is at the same time dark and bright, male and female. In Levine's recording (1985) the phrase is voiced even more homogenously, and because of its much slower tempo, the Neutral lingers longer. The vocal intensification in the word 'Liebe' is quite effective; however, this is against the prescription of the score, which asks for a soft nuance (piano). Perhaps there is a touch of rapture in the otherwise perfect unison with the very last syllable 'Willen' which lets through slightly more tenor timbre.

Both Boulez 1970 and Levine 1985 offer rare moments of asserting the Neutral by having tenors and altos intertwined to one voice with a balanced mixture of both female and male timbres. The difference between these two with Knappartsbusch's 1962 recording is that while both Boulez 1970 and Levine 1985 unfold the Neutral in simultaneous oscillation, in Knappertsbusch 1962 the Neutral oscillates in succession (and with dominating altos). Referring to Leonardo, Wagner spoke about seeing in Christ a woman and a man at the same time. This applies for my listening experience too. According to Barthes,

[...] we might perhaps say that the Neutral finds its feature, its gesture, its inflection embodied in what is inimitable about it: the smile, the Leonardian smile analyzed by Freud: Mona Lisa, St. Anne, Leda, St. John, Bacchus: smiles at the same time of men and women, smiles-figures in which the mark of exclusion, of separation cancels itself, smiles that circulate from one sex to the other [...]. (Barthes 2005: 195)

Listening revealed that although the vocal Neutral had a clear grounding in Wagner's score, its audibility was not automatically assured; in the case of Muck (1927) and Boulez (1966) it did not materialize at all. Perhaps they could be considered as examples of anti-Neutral because only one predominant vocal gender had to be chosen, in the Muck's case it was the tenors and in Boulez's production the altos, voicing both a kind of tyranny of vocal paradigm, but in different ways. A visual metaphor, relevant in this particular case would be Richard Wagner's opinion about Christ's head in the sketches for the Last Supper; it was too feeble (weichlich) or perhaps 
also effeminate (weiblich); the point here being a kind of tyranny of a single gender paradigm.

Listening these pieces of music as foils for the Neutral retuned my ears for the micro-differentiations of vocal qualities in this choral passage. It enhanced a new kind of listening that focussed on the intimate oscillation of vocal genders. However, the more standard modes of listening, e.g. the exactness of the pitches, rhythms, tempo, melodic profile, phrasing, and harmonic progression were not exactly bypassed but they remained in the shadow of the vocal Neutral. Beside passionate and engaged, my listening was also very focused and conscious. The edited examples offered a good chance for this. But, as this article concerns voice in a Barthesian context, a pivotal question remains: was there jouissance? And how does jouissance relate to the Neutral?

As mentioned above, Barthes's autobiography lists jouissance as one possible Figure of the Neutral. However, this is a line of thought which he did not develop in his lecture series (Barthes 2005). Both jouissance and the Neutral situate in the threshold of signification and signifying because they both outplay the paradigms. This is what they have in common. But whereas there are qualitative and significatory differences within the Neutral, as exemplified by Barthes himself (2005), jouissance unfolds as undifferentiated singular, as absence of signification, loss of self. Symptomatically, there is no headword for jouissance in Plaisir du texte (Barthes 1990) as it cannot be defined, but there is a whole lecture series about diverse shades of the Neutral.

In my analytical working there were times that I did not have words for what I heard, and occasionally I had to reach for them with an effort. These absences of language might approach the threshold of jouissance. But it worked also the other way round; with the help of words, concepts, naming and signification, my listening became more precise: the ability to reach for the audible Neutral emerged, not as a singular revelation but in conjunction with other modes of signification; bodily, visual, textual, biographical, spatial. 


\section{Conclusion: Signification and Voice reconsidered after Barthes}

Beside voice and signification, Barthes was also suspicious about music and signification, and he did not recognise the semantic possibilities of music or its enormous power to signify in a given culture (e.g., Barthes 1997b: passim). "Then what is music?" asks Barthes, and answers immediately relying on Panzéra's art: " $a$ quality of language" (Barthes 1997b: 284; emphasis in the original). Therefore it is not surprising that there is not much said about music in Barthes's lecture series; Barthes (2005: 103) for instance mentions that music is "a drug-consciousness." For his defence it must be remembered that Barthes (1915-1980) died before the bloom of musical semiotics, particularly its semantic branch. Of this major corpus, ${ }^{21}$ only Tarasti's Myth and Music (1978) had been published. Nattiez's early pieces, for instance his seminal Fondements d'un sémiologie de la musique (1975) does not address the semantic dimension of music.

As is well known, Barthes was a great admirer of Charles Panzéra (1896-1976), a French baritone singer. It is wrong to assume that Barthes loved Panzéra's voice per se. He loved something else: "I myself have a lover's relation to Panzéra's voice: not to his raw, physical voice, but to his voice as it passes over language, over our French language, like a desire: no voice is raw; every voice is steeped in what it says" (Barthes 1997b: 280). By this Barthes actually denies the existence of voice disengaged from the language. Panzéra's way to articulate French ravishes Barthes, not Panzéra's voice [sa voix brute]. Similarly, Barthes's dislike for Dietrich Fischer-Dieskau (1925-) is not caused by his voice but his way of singing in German (!) language (Barthes 1997a: 269-273). Again, there is no voice alone for Barthes. Yet, in The Romantic Song, Barthes (1997c) acknowledges the familiar voice types in opera, bass, mezzo [contra-alto, sic!], soprano and tenor but here nor elsewhere does he address the voice pertaining to signification (see Richardson 1999 for a very different reasoning below). For Barthes, voice as a quality offers a highway to jouissance, beyond meaning and language. Adriana Cavarero, for one, has critized Barthes for this:

21 See also Grabócz 1986; Tarasti 1994; Monelle 1991; and Hatten 1994. 
Indeed, in Barthes's writing, the voice and body are categories of depersonalized pleasure $[\text { sic! }]^{22}$ in which the embodied uniqueness of each existent (something Barthes never thematizes) is simply dissolved along with the general categories of the subject and the individual. In other words, Barthes encourages us to focus on a vocality that far from being pure and simple sonority, or a mere bodily remainder, consists in a power relating to speech. And, at the same time, he discourages every perspective that would find in uniqueness and in relationality the fundamental sense of this power. (Cavarero 2005: 15)

Cavarero's own recipe is to address unique personal qualities in saying instead of concentrating on the semantics of what was said. By this she wants to free voices from the prison house of logo-centrism where they have been given a subservient role in relation to the semantic dimension of the language ('meaning') while their uniqueness has been ignored (Cavarero 2005: passim). Cavarero's programme leaves me puzzled because it seems to entail that also for her voice alone would not signify except for its uniqueness and that it is always someone's voice. For me this is not enough. When faced with voice and signification I refuse to back off and join the company of Barthes and Cavarero. The voices do have the ability to signify, not just something in general and in theory, but also something specific and in lived-in practice.

Yet I do not wish to deny the enormous power of music and voice to arouse, seduce or ravish, but this need not to be divorced from signification. In one of the early pioneering studies on voice and gender, Elizabeth Wood (1994: 27) explores a mode of listening that has a similar undercurrent to Barthes's erotic listening related to genosong, the materiality of the body in voice (Barthes 1997a: 270-271). However, Wood's theoretical approach stems from elsewhere, from feminism and gender studies (for instance, Cixous), and not from Barthes at all. Wood's Sapphonics is a lesbian space for making emotional and erotic relationships among those who sing and listen singing. A Sapphonic voice resonates in and about lesbian difference and desire and it challenges the boundaries of voice types as well as sex and gender categories, refusing hence standard categorization

22 There is a grave error in translation. In the Italian original (Cavarero 2003: 22) the term is godimento, which should have been translated as jouissance (or bliss). In her original Italian Caverero (2003) makes a systematic distinction between piacere (pleasure) and godimento (jouissance), not respected by the translator. 
(Wood 1994: 28, 30). The binary division is surpassed in a Sapphonic vocal synthesis of female and male voices to a transvestic enigma (Wood 1994: 32). Such a synthesis may be found within one voice only. As exemplary cases for the Sapphonics and Sapphonic voice Wood mentions the low baritonisque register of Pauline ViardotGarcia (1821-1910), the castrato-like falsetto register of Emma Calvé (1858-1940), and their effects on the listeners (Wood 1994: 29-33). Wood's Sapphonics and Sapphonic voice resonates strongly with Barthesian Neutral and more precisely with his Androgyne with that important (dare I say: essential) difference that Wood listens and desires unambiguously as a lesbian, and furthermore, she brings this into her apprehension. In Barthes the subject often (although not exclusively) has a male basis, even when he writes about his Neutral or Androgyne: "Neuter: "a man in whom there is feminine." But perhaps not just any feminine (perhaps there are many of them)" (Barthes 2005: 194; cf. also Dame 1994: 146-147).

Wayne Koestenbaum (1993) listens and desires opera and operatic voices explicitly fuelled by homosexual desire, more precisely that of an Opera Queen. His surprising parallels of gay and opera culture celebrate gay jouissance in every fold of his exposition. In the end of the book he makes a long list of queer moments in the standard opera repertoire, which enhance gay sensitivity. For my purposes the chapter Queen's Throat, which in fact extends also to other vocal organs, is the most poignant. Falsetto voice, compared with chest voice, is deemed artificial, effeminate and unnatural (and Koestenbaum finds it parallel to homosexuality; 1993: 164-165). It is in the threshold of the registers, for instance head vs. chest, where the split within one voice between male and female occurs (Koestenbaum 1993: 166-167). I find this culturally coded division significant also when listening to a group of voices, hearing female and male timbres and registers resonating either simultaneously or in a tight succession. Their inseparable intertwinement calls for the Barthes's Neutral.

In his book on Philip Glass's opera Akhnaten (1983) John Richardson (1999: 137-157) discusses the vocal gender of the main character, the Egyptian pharaoh Akhnaten, whom Glass has cast as a countertenor, a possible vocal follow-up for castrati (Dame 1994: 149). In Akhnaten the vocal colour of a countertenor is highly significant as an aural embodiment for a transgressive gender. The trio with Akhnaten, his wife Nefertiti (contra-alto), and his mother Queen Tye 
(lyrical soprano) is a vocal power play between these three characters, imbued with manifold erotic bondings. In the fourth and fifth stanzas of the trio Akhnaten is vocally capsulated by his mother from above and his wife from below which positions him in an in-between state in many ways:

Caught between what he perceives as divine and earthly love, Akhnaten elects to partake of both. What is more, he evidently views this equilibrium between the internal and the external, between inbreeding and outbreeding, as further evidence of his own semidivine status. One who combines the masculine and the feminine; who traverses the path between the mundane and the eternal [...]. (Richardson 1999: 155)

What Richardson describes here would undoubtedly make a case for multiple Figures of the Neutral, not just Androgyne (e.g. Ideospheres, Rites, Retreat, Oscillation). Voice and more precisely vocal registers are one significant factor in this, and as Richardson shows, they are inseparably intertwined with other modes of signification (here for instance ideological, visual, and textual).

Välimäki's (2005: 301-327) research on k. d. lang's vocalism is a particularly nuanced criticism of Barthes's central concepts, including jouissance, geno-song, feno-song, signifying and the Grain of the Voice which she combines with acoustic mirror. When put to strict scrutiny, the dividing line between geno-song (body as voiced) and feno-song (voice as communication) turns out to be much more problematic than Barthes's article (1997a) would have it. On the basis of her analysis she concludes that no feature is purely pheno or geno. Also the very act of researching turns any 'genuine' geno to feno, by naming it. The same notion concerns also signification and signifying in the act of listening (Välimäki 2005: 326). Thus in the practice of analysis their borderlines — possible hideouts for the Neutral remain in constant oscillation.

Koestenbaum, Wood, Richardson and Välimäki address voice in a way that combine erotic desire and signification. Their writings show that the binary splits between voice and body or body and language, signifying and signification need not to be permanently postulated. Thus they pave a way towards an understanding that bridges voice, language, meanings and desire in culture and in particular sub-cultures embraced also in this article. Their research, as I have above attempted to show how, also resonates with Barthes's Neutral. 
Besides the famous jouissance, signifying etc., there are a myriad of concepts and designations in Barthes's oeuvre that may enhance sensitivity regarding voice and its modes of signification. Barthes's somewhat limited views on music and voice need not to restrain from profiting his semiotic theorising and his reasoning, which can be adapted for musical instances. This kind of research can be further enhanced by combining Barthes's semioticing with other more specific conceptions on voice and vocal cultures. Even though this is not a path taken by Barthes himself, it nevertheless is a valid option. The price to pay would be the loss of not-knowing, un-fetishizing sound, voice and music. As Susanna Välimäki puts it:

We may truly be looking for something as uncoded as possible (the signifiance evading the tyranny of communication and signification) but the moment we find it, it becomes coded. [...] For example, to hunt the grain of voice in [k.d.] lang's music transforms our quarry into a code. Research cannot be done without a system and an explicated research setting. This is a problem that Barthes did not bother to address. (Välimäki 2005: 326)

Agreed. Within Barthesian frame all the music undoubtedly could be deluged into jouissance. But music and vocal qualities need not to be doomed to remain as jouissance only, despite what Barthes himself continuously postulates in writing. Rather than studying voice Barthes suggested another interesting approach: to study the resistances that prevent from addressing voice (Barthes 2005: 78-79). Such a project could well start from his own writings. ${ }^{23}$

\section{References}

Barthes, Roland 1970. Masculin, féminin, néutre. In: Pouillon, Jean; Maranda, Pierre (eds.), Échanges et communications, tome II. The Hague: Mouton, 893-907.

- 1977. Fragments d'un discours amoureux. Paris: Seuil

23 Earlier version of this paper was delivered in the international symposium Barthes's Relevance Today, organised by Harri Veivo, University of Helsinki, Dec. 13-14, 2007. I thank Harri for this inspiring forum as well as his encouragement to do research on The Neutral. I also thank him, John Richardson and Laura Wahlfors for their accurate comments on the previous version of this paper. 
- 1984. Writing Degree Zero. London: Jonathan Cape. [Trans. Lavers, Annette; Smith, Colin.]

- 1987. Criticism and Truth. London: The Athlone Press. [Trans. Pilcher Keuneman, Katrine.]

- 1990. The Pleasure of the Text. Oxford: Basil Blackwell. [Trans. Miller, Richard.]

— 1992. S/Z. Oxford: Basil Blackwell. [Trans. Miller, Richard.]

- 1994. Barthes by Barthes. Berkeley: University of California Press. [Trans. Howard, Richard.]

- 1995. Barthes par Barthes. Paris: Seuil.

- 1997a. The grain of the voice. In: The Responsibility of Forms. Critical Essays on Music, Art, and Representation. Berkeley: University of California Press, 267-277. [Trans. Howard, Richard.]

- 1997b. Music, voice, language. In: The Responsibility of Forms. Critical Essays on Music, Art, and Representation. Berkeley: University of California Press, 278-285. [Trans. Howard, Richard.]

— 1997c. The Romantic Song. In: The Responsibility of Forms. Critical Essays on Music, Art, and Representation. Berkeley: University of California Press, 286-292. [Trans. Howard, Richard.]

- 2002. Le Neutre. Cours au Collège de France (1977-1978). Paris: Seuil/Imec. [Ed. Clerk, Thomas.]

- 2005. The Neutral. Lecture Course at the the Collège de France (1977-1978). New York: Columbia University Press. [Trans. Krauss, Rosalind E.; Hollier, Denis.]

Bie, Oscar 1931. Richard Wagner und Bayreuth: 84 Bilder. Zürich: Orell Füssli.

Cavarero, Adriana 2003. A più voci. Filosofia dell' espressione vocale. Milano: Feltrinelli.

- 2005. For More than One Voice: Toward a Philosophy of Vocal Expression. Stanford: Stanford University Press. [Trans. Kottman, Paul A.]

Clapton, Nicholas 2004. Moreschi. The Last Castrato. London: Haus Publishing.

Dame, Joke 1994. Unveiled voices: Sexual difference and the castrato. In: Brett, Philip; Wood, Elizabeth; Thomas, Gary (eds.), Queering the Pitch: The New Gay and Lesbian Musicology. New York, London: Routledge, 139-153.

Díaz de Chumaceiro, Cora 1993. Richard Wagner's life and music: What Freud knew. In: Feder, Stuart; Pollock, George; Karmel, Richard (eds.), Psychoanalytical Explorations in Music II. Madison: International Universities, 249278.

Dolar, Mladen 2006. A Voice and Nothing More. Cambridge: The MIT Press.

Freud, Sigmund 1984. Leonardo da Vinci. A Memory of his Childhood. London: ARK Paperbacks. [Trans. Richards, Anna.]

Geck, Martin; Voss, Egon (eds.) 1970. Richard Wagner: Sämtliche Werke, Band 30. Dokumente zur Entstehung und ersten Aufführung des Bühnenweihfestspiels Parsifal. Mainz: B. Schott' Söhne.

Glasenapp, Carl Friedrich 1905a. Das Leben Richard Wagners, Band III [4. Auflage]. Leipzig: Breitkopf \& Härtel. 
— 1905b. Das Leben Richard Wagners, Band VI [4. Auflage]. Leipzig: Breitkopf \& Härtel.

Grabócz, Márta 1986. Morphologie des oeuvres pour piano de Liszt. Influence du programme sur l'évolution des formes instrumentales. Budapest: MTA Zenetudományi Intézet.

Gregor-Dellin, Martin 1980. Richard Wagner. Sein Leben - Sein Werk - Sein Jahrhundert. München: Piper.

Gutman, Robert 1968. Richard Wagner. The Man, His Mind, and His Music. New York: Harcourt, Brace \& World.

Hatten, Robert 1994. Musical Meaning in Beethoven: Markedness, Correlation, and Interpretation. Bloomington: Indiana University Press.

Kinderman, William 1995. Die Entstehung der "Parsifal"-Musik. Archiv für Musikwissenschaft 52(1): 66-97.

Koestenbaum, Wayne 1993. The Queen's Throat. Opera, Homosexuality and the Mystery of the Desire. St. Ives: Penguin Books.

Krauss, Rosalind E; Hollier, Denis 2005. Translators' preface. In: Barthes 2005: xiii-xvii.

Mannering, Douglas 1987. The Art of Leonardo da Vinci. [London:] Optimum Books.

Minor, Ryan 2005. Wagner's last chorus: consecrating space and spectatorship in Parsifal. Cambridge Opera Journal 17(1): 1-36.

Monelle, Raymond 1991. Structural semantics and instrumental music. Music Analysis 10(1-2): 73-88.

Nattiez, Jean-Jacques 1975. Fondements d'une sémiologie de la musique. Paris: Union Générale d'Éditions.

- 1993. Wagner Androgyne: A Study in Interpretation. Princeton: Princeton University Press. [Trans. Spencer, Stewart.]

Porges, Heinrich 2002. "Das Orchester muss wie die unsichtbare Seele sein." Richard Wagners Bemerkungen zum "Parsifal." Aufgezeichnet während der Proben und Aufführungen 1882. Berlin: Deutsche Richard-WagnerGesellschaft. [Ed. Pohl, Rüdiger.]

Richardson, John 1999. Singing Archaeology: Philip Glass's Akhnaten. Hanover: Wesleyan University Press.

Sivuoja-Gunaratnam, Anne 1993. The libretto of Parsifal read through the Greimasian mythical actant model. In: Tarasti, Eero (ed.), On the Borderlines of Semiosis. Acta semiotica Fennica II. Imatra: International Semiotics Institute at Imatra, 335-348.

- 2007. Barthes, ääni-kieli ja musiikki. [Barthes, voice-language and music]. In: Veivo, Harri (ed.), Vastarinta / Resistanssi: konfliktit, vastustus ja sota semiotiikan tutkimuskohteina. Helsinki: The Helsinki University Press, 54-73.

- forthcoming 2008. Parsifal as the undoing of Kundry. In: Kukkonen, Pirjo; Vierimaa, Irma; Veivo, Harri; Hatten, Robert; Littlefield, Rick (eds.), $A$ Sounding of Signs: Modalities and Moments in Music, Culture, and Philosophy. Essays in Honor of Eero Tarasti on his 60th Anniversary. Imatra: International Semiotics Institute. 
Skelton, Geoffrey 1965. Wagner at Bayreuth: Experiment and Tradition. London: Barrie \& Rockliff.

Smart, Mary Ann 2000. Introduction. In: Smart, Mary Ann (ed.), Siren Songs: Representation of Gender and Sexuality in Opera. Princeton: Princeton University Press, 3-16.

Stein, Leon 1950. The Racial Thinking of Richard Wagner. New York: Philosophical Library.

Tarasti, Eero 1978. Myth and Music. A Semiotic Approach to the Aesthetics of Myth in Music, especially that of Wagner, Sibelius and Stravinsky. (Acta Musicologica Fennica 11.) Helsinki: The Musicological Society of Finland.

- 1994. A Theory of Musical Semiotics. Bloomington: Indiana University Press.

Välimäki, Susanna 2005. Subject Strategies in Music. A Psychoanalytic Approach to Musical Signification. (Acta Semiotica Fennica 22. Approaches to Musical Semiotics 9.) Imatra: International Semiotics Institute at Imatra.

Wagner, Cosima 1982a. Die Tagebücher, Band II: 1873-1877. [2. Auflage.] München: Piper.

— 1982b. Die Tagebücher, Band III: 1878-1880. [2. Auflage.] München: Piper.

- 1994. Cosima Wagner's Diaries: An Abridgement. London: Pimlico. [Ed. Skelton, Geoffrey.]

Wagner, Richard 1992. My Life. New York: Da Capo Press. [Trans. Gray, Andrew.]

Weiner, Marc A. 1997. Richard Wagner and the Anti-Semitic Imagination. Nebraska: University of Nebraska Press.

Wolzogen, Hans von [s. a.]. Parsifal: ein thematischer Leitfaden durch Dichtung und Musik. 21st edition. Leipzig: Georg Esseger.

Wood, Elizabeth 1994. Sapphonics. In: Brett, Philip; Wood, Elizabeth; Thomas, Gary (eds.), Queering the Pitch. The New Gay and Lesbian Musicology. New York: Routledge, 27-66.

\section{Music Sources}

Wagner, Richard 1882. Parsifal. Bühnenweihfestspiel in 3 Aufzügen.

Scores:

- Ernst Eulenburg (London, s. a.).

— G. Schirmer (New York, 1904). Arrangement by Karl Klindworth.

Recordings:

Muck, Karl 1927. Bayreuth Festival Chorus and Orchestra. Naxos 8.110049-50 (1999).

Knappertsbusch, Hans 1951. Bayreuth Festival Chorus and Orchestra. Teldec Classics International 9031-76047-2 (1993).

- 1962. Bayreuth Festival and Orchestra. Philips 416 390-2 (s.a.).

- 1964. Bayreuth Festival Chorus and Orchestra. Orfeo D'or C 690074 L (2007). 
Boulez, Pierre 1966. Bayreuth Festival Chorus and Orchestra. Golden Melodram GM 1.0037 (2000).

- 1970. Bayreuth Festival Chorus and Orchestra. Deutsche Grammophon DG 435718-2 (1971).

Levine, James 1985. Bayreuth Festival Chorus and Orchestra. Philips 416842-2 (1987).

\section{Озвучивание Нейтрального в Невидимом хоре «Парсифаля» Рихарда Вагнера}

Многие работы Ролана Барта свидетельствуют о том, что Барт был скептичен в вопросах способности к означиванию музыки и голоса. В то же время его несколько ограниченное понимание музыки и голоса не значит, что мы не можем использовать его семиотические теории, поскольку неучтенным самим Бартом образом их можно применить и при анализе музыкальных произведений. «Нейтральное» (Le Neutre) является повторяющейся темой в работах Барта, начиная с его первой работы «Нулевая степень письма» (1953) и кончая серией лекций 1978 года в Коллеж де Франс, посвященных понятию «нейтральное». Данная статья анализирует, каким образом бартовское «нейтральное» способствует слушанию определенного типа. Материалом анализа являются загадочные звуки, производимые Невидимым хором в «Парсифале» Ричарда Вагнера, точнее одна конкретная фраза в первом акте ("Nehmet hin meinen Leib [...]"). В данном случае нас интересует не столько семантика этой фразы, столько то, как эта фраза озвучена и как в этой фразе и на ее фоне доносится бартовское «нейтральное». Слушание этого «нейтрального» возможно по нескольким концертным записям. Мой анализ показывает, что «нейтральное» не является чем-то обособленным, а действует вместе с другими видами обозначения (визуальное, текстуальное, биографическое).

\section{Neutraalsele hääle andmine Richard Wagneri Parcifali Nähtamatus Kooris}

Mitmed Roland Barthes'i tööd annavad tunnistust sellest, et Barthes oli skeptiline muusika ja hääle tähistamise võime suhtes. Samas ei tähenda tema enda pisut piiratud arusaam muusikast ja häälest seda, et me ei tohiks tema semiootilistest teooriatest ja mõttearendustest inspiratsiooni ammutada, kuivõrd neid on võimalik muusikalistele allikatele rakendada 
Barthes'i enda poolt ettearvamatutel viisidel. 'Neutraalne' (Le Neutre) on korduv teema Barthes'i töödes, alates tema esimesest teosest Kirja nullaste (1953) kuni 1978. aasta 'neutraalse' mõistele pühendatud loenguseeriani Collège de France' is (avaldatud 2002. aastal). Käesolev artikkel analüüsib seda, kuidas Barthes'i 'neutraalne' soodustab teatud sorti kuulamist. Analüüsi taustaks on mõistatuslikud helid, mille toob kuuldavale Nähtamatu Koor Richard Wagneri Parsifalis (1882), täpsemini üks konkreetne fraas altide ja tenorite esituses ("Nehmet hin meinen Leib [...]", esimene vaatus). Antud juhul ei huvita meid niivõrd (kirja)keele abil esitatud semantiline sisu, vaid see, kuidas nimetatud fraas on kuuldavale toodud ja täpsemalt, kuidas selle fraasi sees ja taustal kostub Barthes'i 'neutraalne'. 'Neutraalse' kuulamine on võimalik mitmes Bayreuthis tehtud kontsertlindistuses. Mu analüüs näitab, et 'neutraalne' ei ole midagi eraldiseisvat, vaid toimib koos teiste tähistamisviisidega (visuaalse, tekstuaalse ja biograafilisega). 
